\title{
Preliminary Assessment of Trace Metal Pollution and Their Bioaccumulation in Mollusks Inhabiting the Intertidal Sediments of the Atlantic Coast of Accra, Ghana
}

\author{
Emmanuel R. Blankson (D, Thyra F. Addison, Daniel Oduro, Juliet Ewool, \\ and Francis Gbogbo \\ Department of Animal Biology and Conservation Science, School of Biological Sciences, University of Ghana, Accra, Ghana \\ Correspondence should be addressed to Emmanuel R. Blankson; erblankson@gmail.com
}

Received 31 October 2021; Accepted 10 January 2022; Published 1 February 2022

Academic Editor: Valerio Matozzo

Copyright ( $\odot 2022$ Emmanuel R. Blankson et al. This is an open access article distributed under the Creative Commons Attribution License, which permits unrestricted use, distribution, and reproduction in any medium, provided the original work is properly cited.

\begin{abstract}
The present study investigated the trace metal levels in sediments, enrichment in sediments, and its bioaccumulation in mollusks collected from the intertidal sediments of the coast of Accra, Ghana, which is influenced by anthropogenic activities. The metals $(\mathrm{Fe}, \mathrm{Mn}, \mathrm{Cu}, \mathrm{Cr}$, and $\mathrm{Zn}$ ) were analyzed in sediments. The metals $(\mathrm{Mn}, \mathrm{Cu}, \mathrm{Cr}$, and $\mathrm{Zn})$ were analyzed in the soft tissue of the mollusks collected from the different coastal areas. The results indicate that although Accra is the capital city and the coast receives tons of anthropogenic wastes, trace metal levels were low and there was no enrichment for the metals analyzed except Cu which showed minor to moderate enrichment in the coastal sediments. There was bioaccumulation of the trace metals in the soft tissue of the mollusks, and the results suggest that the mollusks studied, the gastropods (Agaronia razetoi) and the bivalves (Tivela tripla), can be used for biomonitoring.
\end{abstract}

\section{Introduction}

Trace metal pollution remains an environmental concern around the world. This is because metals are persistent in the environment and can cause toxic effects on organisms including humans [1-3]. Metals occur naturally in the environment, but their levels can be increased through anthropogenic sources such as mining, informal e-waste recycling, sewage treatment processes, and automobile emissions [4-6]. From these anthropogenic sources, most trace metals are transported by rivers, streams, and atmospheric deposition to marine ecosystems where they end up in the sediment by binding to suspended solids [7]. The extent of accumulation of metals in sediments and their bioavailability to aquatic organisms depends on the metal and sediment characteristics such as the organic content, particle size, $\mathrm{pH}$, presence of iron and manganese oxides, pore-water ligands, and redox potential. [8-11].
Metals in sediment bioaccumulate in benthic invertebrates and present a potential health risk when they are fed on by organisms at higher trophic levels. As a result of the potential risk of metal exposure to organisms, metals are monitored by determining metal levels in sediment, water, and in the tissues of aquatic organisms such as fish, mollusk, and other invertebrates [12].

Generally, benthic macroinvertebrates are used for biomonitoring to assess the extent of environmental pollution. However, the species selected for biomonitoring is very important, and in the present study, we used mollusks because they are abundant with restricted movement to a particular local environment $[12,13]$. They are also good bioindicators of environmental contamination because they bioaccumulate contaminants [12]. Among the mollusks, bivalves are preferred for biomonitoring, but previous studies have shown that gastropods can also be used for biomonitoring in aquatic environments $[12,14]$. 
Accra, like most major cities in West Africa, is along the coast of the Gulf of Guinea. Accra is characterized by high population growth, urbanization, informal e-waste recycling, and industrial activities which contribute to the trace metal load along the coast of Accra. Previous studies have investigated metals in fish, bivalves, and gastropods $[15,16]$, and other studies have investigated metals in sediment or seawater from the coastal environment of Ghana [17-19]. However, studies that have investigated how metal concentrations in sediments influence their bioaccumulation in benthic invertebrates along the coast of Ghana and the Gulf of Guinea are rare. Therefore, in the present study, we investigated the extent of trace metal pollution along the Accra coast of the Gulf of Guinea, enrichment in sediments, bioaccumulation in mollusks, and the potential use of mollusks for biomonitoring. The importance of such findings in understanding metal pollution and bioaccumulation trends of trace metals in mollusks along the coast of the Gulf of Guinea compared to other coastal regions of the world cannot be neglected.

\section{Materials and Methods}

2.1. Study Area. The Accra coast is part of the Gulf of Guinea which is a large marine ecosystem on the Atlantic coast of West Africa. The Accra coast is the coastline of Accra, the capital city of Ghana which has lots of industries and is characterized by rapid urbanization. The coastline is approximately $40 \mathrm{~km}$ long, and it has a high population density, which is characterized by various economic activities such as fishing and recreation $[20,21]$. The Accra coast has a tropical climate, and it is characterized by two wet seasons. These are between April and July and another in September-November that influence sediment transport along the coast [20]. The coastline is connected to lagoons through which streams and rivers discharge their content to the sea. The content includes domestic and industrial wastes which contribute to anthropogenic pollution along the coast of Accra, Ghana.

2.2. Field Sampling. The sediment samples were collected from intertidal sediments of four coastal areas along the Accra coast which are highly populated and influenced by anthropogenic activities such as urbanization and industrialization. These are Sakumono (S1), Teshie (S2), Korle Gonno (S3), and Jamestown (S4) coasts and are referred to as Site 1, Site 2, Site 3, and Site 4, respectively (Figure 1). Sakumono coast (S1) is close to the city of Tema, which has a lot of industries and a port. It is about $14.5 \mathrm{~km}$ away from the area with many industries and $8 \mathrm{~km}$ from the port. The Teshie (S2), Korle Gonno (S3), and Jamestown (S4) coasts are about $16 \mathrm{~km}, 7.4 \mathrm{~km}$, and $8 \mathrm{~km}$, respectively, from the area in the city of Accra with many industries. At each of the coastal areas, we collected the sediment with a corer with an area of $0.011 \mathrm{~m}^{2}$ along a transect from three different sites at a depth of $15 \mathrm{~cm}$ in the intertidal area. The sediments collected from the different sites were placed in ziplock bags and transported to the laboratory for analysis of $\mathrm{Fe}, \mathrm{Mn}, \mathrm{Cu}$,
$\mathrm{Zn}$, and Cr. At each of the coastal areas, mollusks in the coastal sediments were collected by hand from the sites and transported on ice to the laboratory where they were stored at $-20^{\circ} \mathrm{C}$ until analysis. The same mollusk species were not present at all the sites; we, therefore, collected the mollusks that were present at the different sites. We collected 17 and 2 individuals of the gastropods Agaronia razetoi from Sites 1 and 2, respectively, while at Site 3, there was no Agaronia razetoi; therefore, we collected 15 individuals of the bivalve Tivela tripla. We however did not find any mollusk in the sediment at the time of sampling at Site 4 .

\subsection{Analysis}

2.3.1. Organic Matter and Silt/Clay Content. The sediment organic matter and silt/clay content were quantified for the sediments collected from the four coastal areas along the coast of Accra (Table 1). The silt/clay content was determined by sieving a wet subsample of sediment through a $63 \mu \mathrm{m}$ mesh sieve. The sediment samples that were sieved and the fraction that was retained on the mesh were then dried at $60^{\circ} \mathrm{C}$ for $48 \mathrm{~h}$ and weighed. The organic matter in sediment was quantified using the loss-on-ignition method where approximately $1 \mathrm{~g}$ of ground sediment dried at $60^{\circ} \mathrm{C}$ was placed in a crucible and heated in the muffle furnace at $550^{\circ} \mathrm{C}$ for $4 \mathrm{~h}[22]$.

2.3.2. Trace Metal Analysis in Sediment Samples. The sediment subsamples from the cores were dried in an oven at $60^{\circ} \mathrm{C}$ for $48 \mathrm{~h}$ in opened ziplock bags placed in acid washed beakers. The sediment was ground, and $10 \mathrm{ml}$ of ternary mixture $\left(\mathrm{HClO}_{4}: \mathrm{HNO}_{3}: \mathrm{H}_{2} \mathrm{SO}_{4}, 1: 25: 2.5\right)$ was added to $1 \mathrm{~g}$ of ground sediment in acid washed beakers and digested under a fume hood. After digestion, the samples were filtered into a $100 \mathrm{ml}$ volumetric flask using a Whatman No. 42 filter paper. Distilled water was then added to the filtrate to make it to the $100 \mathrm{ml}$ mark and analyzed with flame atomic absorption spectrophotometry (AAS) on PerkinElmer PinAAcle 900T.

2.3.3. Trace Metal Analysis in Tissue Samples. The soft tissues of mollusks were removed from their shells using stainless steel scalpel blades. The soft tissues were placed in acid washed beakers and dried in an oven at $60^{\circ} \mathrm{C}$ to a constant weight. After quantification of the dry weight, $10 \mathrm{ml}$ of ternary mixture $\left(\mathrm{HClO}_{4}: \mathrm{HNO}_{3}: \mathrm{H}_{2} \mathrm{SO}_{4}, 1: 25: 2.5\right)$ was added to the tissues and digested under a fume hood. After digestion, the samples were filtered into a $100 \mathrm{ml}$ volumetric flask using a Whatman No. 42 filter paper. Distilled water was then added to the filtrate to make it to the $100 \mathrm{ml}$ mark and analyzed with flame atomic absorption spectrophotometry (AAS) on PerkinElmer PinAAcle 900T.

2.3.4. Biota-Sediment Accumulation Factor (BSAF). The BSAF provides a quantification of metal uptake by benthic organisms from the sediment. The BSAF was quantified as the ratio of metal concentrations in the mollusk and the sediments (with both concentrations expressed on a dry weight basis). 


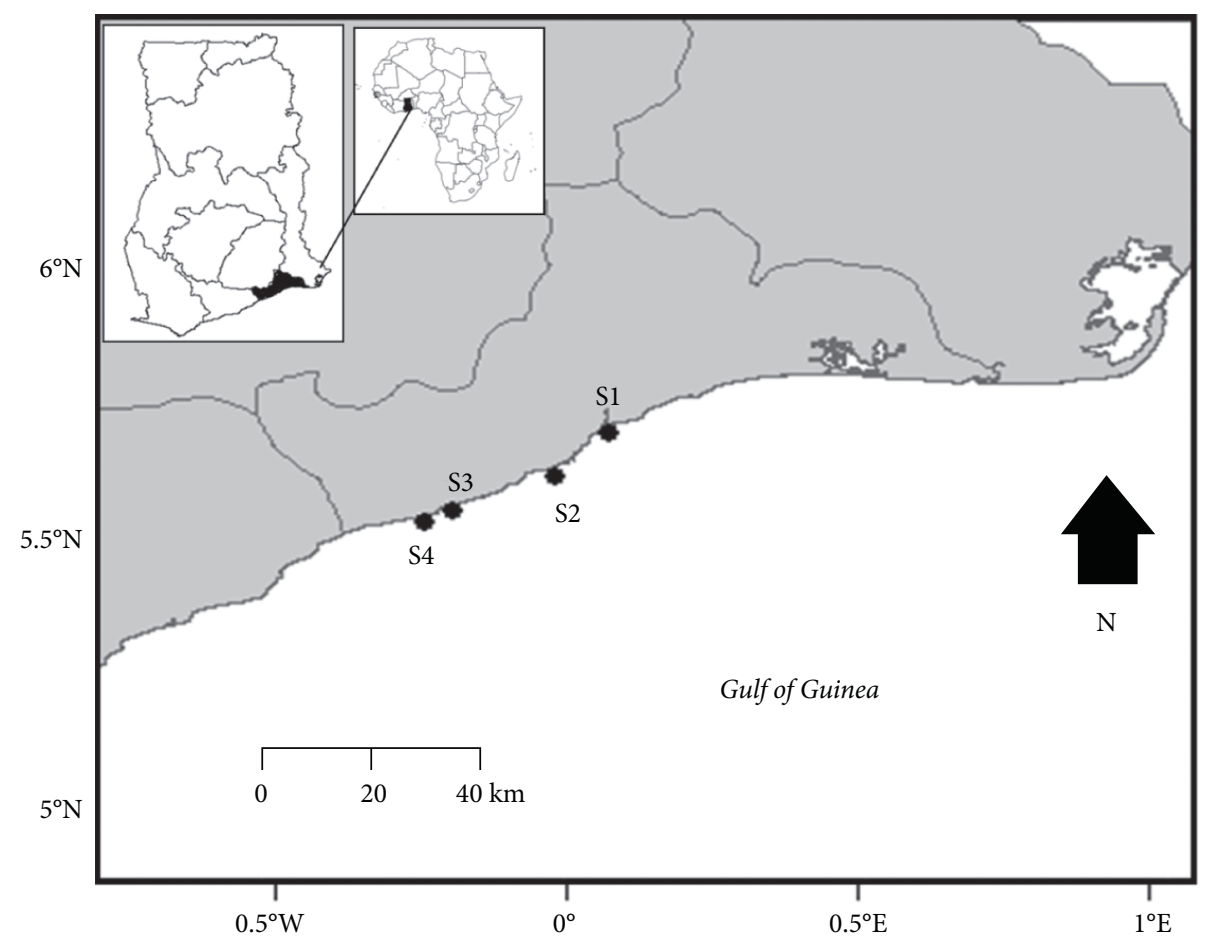

FIGURE 1: Map of Accra coast showing the sampling sites. S1, Sakumono coast; S2, Teshie coast; S3, Korle Gonno coast; S4, Jamestown coast.

TABle 1: The sediment organic matter (OM) and silt/clay (SC) content from the four sampling sites along the coast of Accra.

\begin{tabular}{lcc}
\hline Sites & Organic matter (\%) & Silt/clay content (\%) \\
\hline Site 1 (S1) & $0.96 \pm 0.27$ & $0.05 \pm 0.01$ \\
Site 2 (S2) & $1.49 \pm 0.26$ & $0.24 \pm 0.08$ \\
Site 3 (S3) & $0.94 \pm 0.10$ & $0.16 \pm 0.04$ \\
Site 4 (S4) & $0.73 \pm 0.16$ & $0.21 \pm 0.13$ \\
\hline
\end{tabular}

The values shown are mean \pm SE $(n=3)$.

2.3.5. Enrichment Factor. The anthropogenic input of metals in sediment was assessed using the enrichment factor. The enrichment factor was quantified by normalizing metal concentrations in samples and background concentration to a reference metal $(\mathrm{Fe})$ concentration [23].

The enrichment factor was quantified by the following equation:

$$
\mathrm{EF}=\frac{(\mathrm{CM} / \mathrm{CFe}) \text { sample }}{(\mathrm{CM} / \mathrm{CFe}) \text { background }},
$$

where CM is the concentration of the metal and CFe is the concentration of the reference metal. When $\mathrm{EF}<1$ shows no enrichment, $\mathrm{EF}<3$ shows minor enrichment, $\mathrm{EF}=3-5$ shows moderate enrichment, $\mathrm{EF}=5-20$ shows significant enrichment, $\mathrm{EF}=20-40$ shows very severe enrichment, and EF $>40$ shows extremely high enrichment.

2.3.6. Toxicity Assessment of the Trace Metals in Sediment. To assess the toxicity of trace metals to benthic organisms, we compared the concentration of each metal with the threshold effect levels (TEL). The TEL is a sediment quality guideline (SQG), and metals are considered to be toxic when they exceed the TEL values [24]. We subsequently calculated the toxic units (TU) by dividing the concentration of each metal by the threshold effect levels (TEL). A toxic unit greater than one shows that the metal levels in the sediment are possibly toxic to the benthic organism in the sediment [11].

2.4. Statistical Analysis. The data were checked for normality using the Shapiro-Wilk test. The datasets that were not normal were transformed or analyzed using the Kruskal-Wallis test. A one-way analysis of variance (ANOVA) was used to evaluate differences in $\mathrm{Fe}$ and $\mathrm{Zn}$ in sediments from the different sites. A Kruskal-Wallis test was used to analyze the differences in $\mathrm{Mn}, \mathrm{Cu}$, and $\mathrm{Cr}$ in sediments from the different sites. A one-way analysis of variance (ANOVA) was used to analyze the differences in bioaccumulation and BSAF values of metals in the tissue of mollusks from the different sites. The Pearson correlation was used to analyze the association between trace metals in sediment and sediment organic matter and silt/clay content. All statistical analyses were conducted with $R$ version 3.5.1 [25].

\section{Results}

3.1. Trace Metals in Sediments. The average concentrations of metals in the sediments for all the sites are shown in Table 2. The Fe and Mn concentrations in the sediment on average were higher compared to all the other metals studied. Generally, the concentrations of all the metals were higher at Site 2 (Teshie coast) except for $\mathrm{Cu}$ which was higher at Site 1 (Sakumono coast). There were no significant $(P>0.05)$ 
differences in $\mathrm{Cu}, \mathrm{Mn}$, and $\mathrm{Cr}$ concentrations between the different sites. However, there were significant differences for $\mathrm{Zn}$ and $\mathrm{Fe}$. The $\mathrm{Zn}$ concentrations in the sediment differed significantly $(P<0.05)$ between the sites. The $\mathrm{Zn}$ concentration was highest at Site 2 and lowest at Site 4 . There was a fivefold difference between the highest and lowest concentration. The Fe concentrations in the sediment differed significantly $(P<0.05)$ between the sites. The $\mathrm{Fe}$ concentration was highest at Site 2 and lowest at Site 4 . There was a fourfold difference between the highest and lowest concentration. Fe levels were significantly enhanced at Site 2 compared to the other sites. The toxic units (Figure 2(a)) were less than one for $\mathrm{Cu}, \mathrm{Zn}$, and $\mathrm{Cr}$, thus suggesting no toxicity of these metals in the sediment.

3.2. Enrichment Factor. The result of the enrichment factors (Figure 2(b)) showed no enrichment of $\mathrm{Mn}, \mathrm{Cr}$, and $\mathrm{Zn}$ at all the sites. However, $\mathrm{Cu}$ showed minor to moderate enrichment at all the sites except for Site 2 (Teshie coast) where there was no enrichment. There was moderate enrichment at Site 1 and minor enrichments at Sites 3 and 4 .

3.3. Relationship between Trace Metals and Sediment Properties. The sediment samples collected from the different sites had low organic matter and silt/clay content. The degree of $\mathrm{OM}$ in the coastal sediments from the different sites was in the order of Site $2>$ Site $1>$ Site $3>$ Site 4 . The degree of silt/clay content in the coastal sediments from the different sites was in the order of Site $2>$ Site $4>$ Site $3>$ Site 1. The Pearson correlation between metals, organic matter, and silt/clay content was determined (Table 3 ). Fe in the sediment had a significant $(P<0.05)$ positive correlation with $\mathrm{Zn}$ and $\mathrm{Cr}$. There was a significant positive correlation between $\mathrm{Cu}$ and $\mathrm{Mn}$. There was also a significant positive correlation between $\mathrm{Zn}$ and $\mathrm{Cr}$. The $\mathrm{OM}$ was significantly positively correlated to $\mathrm{Fe}$ and $\mathrm{Cr}$.

3.4. Trace Metals in Mollusks. The average metal concentrations of mollusks sampled in the present study are shown in Table 4 . There was no significant $(P>0.05)$ difference in $\mathrm{Cu}$ and $\mathrm{Cr}$ levels in the tissue of mollusks from the different sites. However, the $\mathrm{Zn}$ concentrations in the mollusk tissue differed significantly $(P<0.05)$ between sites. The highest $\mathrm{Zn}$ concentration was recorded in the mollusk from Site 2 (Teshie coast) and the lowest concentration in the mollusk from Site 3 (Jamestown coast). There was a fivefold difference between the highest and lowest concentrations which was significant. The Cr levels in the tissue of mollusks were low irrespective of the levels in the sediment suggesting low bioavailability of $\mathrm{Cr}$ to the mollusk. A comparison of the metal levels in the mollusk tissue in the present study to other studies $[4,6,10,26]$ shows that the metal levels in the mollusk along the Accra coast of the Gulf of Guinea are within recommended levels.

3.5. BSAF. The BSAF (Table 5) values for $\mathrm{Cu}$ differed significantly $(P<0.05)$ between the sites, and the highest BSAF value was for Site 2 (Teshie coast) and the lowest for Site 1
(Sakumono coast). The BSAF values for $\mathrm{Zn}$ differed significantly $(P<0.05)$ between the sites, and the highest BSAF value was for Site 1 and the lowest for Site 2. The BSAF values for $\mathrm{Cr}$ differed significantly $(P<0.05)$ between the sites. $\mathrm{Cr}$ generally had the lowest BSAF values, and the highest value was for Site 1 and the lowest for Site 2. Generally, for the metals studied, there was a trend where BSAF values were generally lower for the mollusk in sediment with higher metal concentrations.

\section{Discussion}

The concentrations of trace metals along the coast of Accra in the present study were low. However, the concentrations were within the range reported for other coastal areas along the coast of Ghana $[16,17]$. The findings of the present study agree with a previous study [19], which showed that, along the Ghana coast, most trace metal concentrations were low in shallow areas of the continental shelf. A comparison of the metal levels in the present study to what has been reported along the coast in other parts of the world shows that the Accra coast is not polluted with $\mathrm{Cr}, \mathrm{Cu}, \mathrm{Mn}, \mathrm{Zn}$, and $\mathrm{Fe}$ $[10,11,26,27]$. The trace metal levels along the Accra coast were within the recommended range and were below threshold levels in coastal and marine environments [24].

Although Accra is the capital city of Ghana and the coast receives tons of domestic and industrial wastes, the results of the enrichment factors suggest low anthropogenic input of trace metals. For all the metals studied except $\mathrm{Cu}$, our results suggest that they are mainly from natural sources. This is because the results of the enrichment factors showed no enrichment of $\mathrm{Mn}, \mathrm{Cr}$, and $\mathrm{Zn}$ at all the sites. However, $\mathrm{Cu}$ showed minor to moderate enrichment at all the sites except for Site 2 (Teshie coast) where there was no enrichment. Site 1 (Sakumono coast) which had moderate enrichment of $\mathrm{Cu}$ in the sediment is close to Tema, a city in Accra that has a lot of industries and a port, and these may be an anthropogenic source of $\mathrm{Cu}$ to the marine environment. The positive correlations between $\mathrm{Fe}, \mathrm{Zn}$, and $\mathrm{Cr}$ and between $\mathrm{Cu}$ and $\mathrm{Mn}$ suggest that these metals are transported bonded to Fe or Mn oxides/hydroxides and are from a common anthropogenic and geologic origin $[23,28]$. The evaluation of possible toxic effects of these metals by estimation of the toxic units suggests no toxicity of these metals as toxic units were less than one $[11,29,30]$.

The bioaccumulation of metals in the mollusk was not significantly different between the sites for all the metals except Zn. Previous studies have shown that the difference in metal levels in the tissue of mollusks may be due to the concentration of metals, the environment, metabolism and the uptake routes such as diet, or from the ambient environment [9]. In the present study, the mollusk collected from Site 2 (Teshie coast) bioaccumulated more $\mathrm{Zn}$. The difference may be due to the $\mathrm{Zn}$ levels in the sediments and organic matter. This is because sediment in Site 2 on average had more $\mathrm{Zn}$ levels and organic matter compared to the other sites. The bioaccumulation of $\mathrm{Cu}$ in the mollusk may have also been influenced by sediment organic matter. This is because although $\mathrm{Cu}$ levels in sediments from Site 2 
TABLE 2: Heavy metal concentrations $(\mu \mathrm{g} / \mathrm{g})$ in sediments from the sampling sites.

\begin{tabular}{lccccc}
\hline Sites & $\mathrm{Mn}$ & $\mathrm{Cu}$ & $\mathrm{Zn}$ & $\mathrm{Cr}$ & $\mathrm{Fe}$ \\
\hline Site 1 (S1) & $7.76 \pm 4.93 \mathrm{a}$ & $5.27 \pm 3.62 \mathrm{a}$ & $1.30 \pm 0.21 \mathrm{a}, \mathrm{b}$ & $0.87 \pm 0.32 \mathrm{a}$ & $1167.33 \pm 184.85 \mathrm{a}$ \\
Site 2 (S2) & $9.3 \pm 6.0 \mathrm{a}$ & $2.07 \pm 0.33 \mathrm{a}$ & $2.47 \pm 0.58 \mathrm{a}$ & $3.51 \pm 1.52 \mathrm{a}$ & $2642.06 \pm 460.21 \mathrm{~b}$ \\
Site 3 (S3) & $1.63 \pm 0.78 \mathrm{a}$ & $2.20 \pm 0.7 \mathrm{a}$ & $1.37 \pm 0.41 \mathrm{a}, \mathrm{b}$ & $1.55 \pm 0.29 \mathrm{a}$ & $1694.17 \pm 186.50 \mathrm{a}, \mathrm{b}$ \\
Site 4 (S4) & $1.93 \pm 1.23 \mathrm{a}$ & $0.70 \pm 0.25 \mathrm{a}$ & $0.50 \pm 0.15 \mathrm{~b}$ & $0.14 \pm 0.13 \mathrm{a}$ & $659.42 \pm 32.99 \mathrm{a}$ \\
\hline
\end{tabular}

The values shown are mean $\pm \operatorname{SE}(n=3)$.

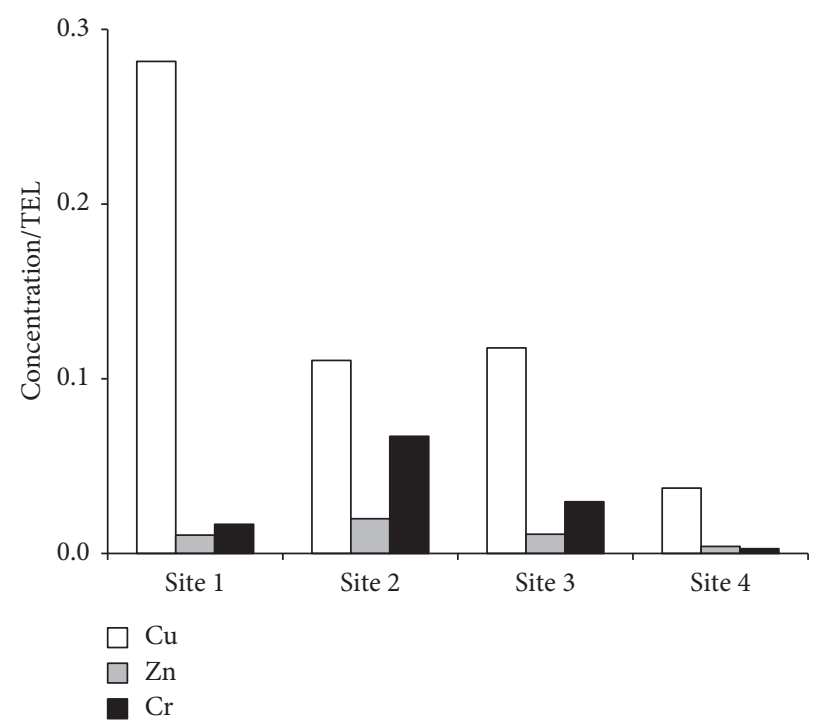

(a)

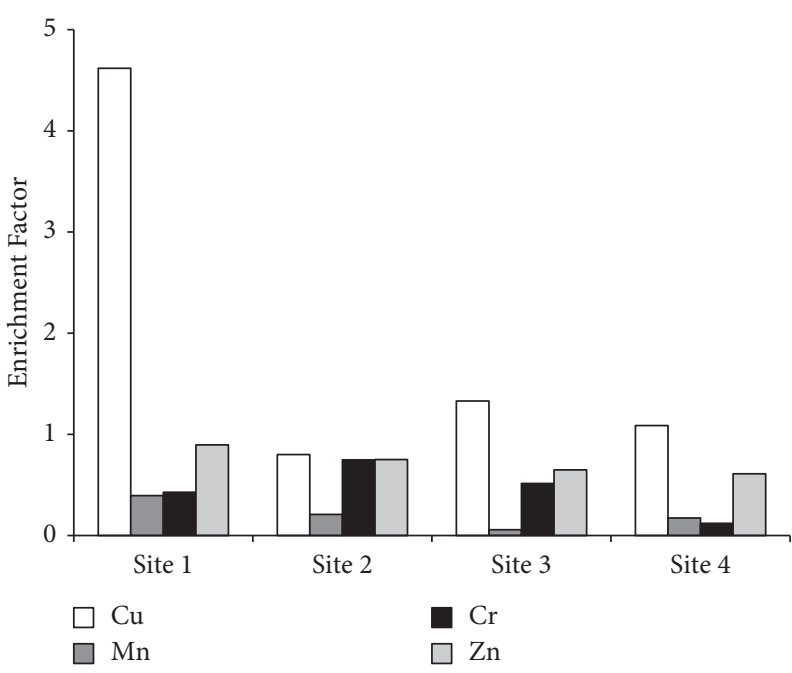

(b)

Figure 2: The toxic units (TU) of heavy metals $(\mathrm{Zn}, \mathrm{Cr}$, and $\mathrm{Cu}$ ) concentration from the sampling sites (a) and the enrichment factor for metals ( $\mathrm{Mn}, \mathrm{Zn}, \mathrm{Cr}$, and $\mathrm{Cu})$ in sediment collected from the sampling sites (b).

TABle 3: Pearson correlation coefficient between metal concentrations, organic matter, and silt/clay content in the sediment.

\begin{tabular}{lccccccc}
\hline & $\mathrm{Mn}$ & $\mathrm{Cu}$ & $\mathrm{Zn}$ & $\mathrm{Cr}$ & $\mathrm{Fe}$ & $\mathrm{OM}$ & $\mathrm{SC}$ \\
\hline $\mathrm{Mn}$ & 1 & & & & & & \\
$\mathrm{Cu}$ & $0.58^{*}$ & 1 & & & & & \\
$\mathrm{Zn}$ & 0.46 & 0.30 & 1 & & & & \\
$\mathrm{Cr}$ & 0.55 & -0.02 & $0.76^{*}$ & 1 & & & \\
$\mathrm{Fe}$ & 0.11 & -0.11 & $0.79^{*}$ & $0.77^{*}$ & 1 & & \\
$\mathrm{OM}$ & 0.30 & -0.25 & 0.55 & $0.86^{*}$ & $0.67^{*}$ & 1 & \\
$\mathrm{SC}$ & 0.24 & -0.23 & 0.19 & 0.47 & 0.16 & 0.45 & 1 \\
\hline
\end{tabular}

$\mathrm{OM}$, organic matter; SC, silt/clay content. ${ }^{*}$ Significant correlation $(P<0.05)$.

were lower than those of Site 1 , the average $\mathrm{Cu}$ levels bioaccumulated were higher in the mollusk from Site 2 than in the mollusk from Site 1. The Cr levels in the mollusk from the different sites were generally low, and Cr levels in the tissue relative to what is in the sediment suggest low bioavailability to the mollusk. This observation agrees with other studies which showed that mollusks do not bioaccumulate $\mathrm{Cr}$ readily from coastal sediments $[9,10,31]$. $\mathrm{Mn}$, although it was detected in the sediments, was below the detection limit in the mollusks' soft tissues. The reason for this observation may be due to very low bioavailability to soft tissues of the mollusk. The other reason may be due
TABLE 4: Heavy metal concentrations $(\mu \mathrm{g} / \mathrm{g})$ in the tissue of the gastropod Agaronia razetoi (Ar) and bivalve Tivela tripla (Tt) from the sampling sites.

\begin{tabular}{lcccc}
\hline Sites & $\mathrm{Cu}$ & $\mathrm{Mn}$ & $\mathrm{Zn}$ & $\mathrm{Cr}$ \\
\hline Site 1 $(\mathrm{S} 1)^{\mathrm{Ar}}$ & $4.575 \pm 1.33 \mathrm{a}$ & $\mathrm{bd}$ & $11.9 \pm 3.42 \mathrm{a}, \mathrm{b}$ & $0.35 \pm 0.01 \mathrm{a}$ \\
Site 2 (S2) ${ }^{\mathrm{Ar}}$ & $7.05 \pm 0.25 \mathrm{a}$ & $\mathrm{bd}$ & $16.3 \pm 1.30 \mathrm{a}$ & $0.28 \pm 0.06 \mathrm{a}$ \\
Site 3 (S3) & $4 \pm 0.73 \mathrm{a}$ & $\mathrm{bd}$ & $3.15 \pm 0.93 \mathrm{~b}$ & $0.32 \pm 0.03 \mathrm{a}$ \\
\hline
\end{tabular}

The values shown are mean \pm SE (with $n=4,2,4$ ) from S1, S2, and S3, respectively. bd, below detection limit.

to more bioaccumulation of $\mathrm{Mn}$ in the shell of the mollusks. It has been reported in other studies that Mn levels may occur at higher concentrations in the shell of some species of mollusks than in the soft tissue $[32,33]$. However, in the present study, we did not quantify trace metals in the shells of the mollusks. Trace metal bioaccumulation has been reported in shells of mollusks [32, 33] and may influence trace metal levels in mollusks' soft tissues. The results suggest that the mollusks (Agaronia razetoi and Tivela tripla) studied in the present study may not be a good bioindicator for $\mathrm{Cr}$ and $\mathrm{Mn}$ pollution. The $\mathrm{Cr}, \mathrm{Zn}$, and $\mathrm{Cu}$ levels bioaccumulated by the mollusk in the present study compared to other studies around the world indicate that the levels in the tissue are low and within the recommended range $[4,10]$. 
TABle 5: Biota-sediment bioaccumulation factors of the gastropod Agaronia razetoi (Ar) and bivalve Tivela tripla (Tt) from the sampling sites.

\begin{tabular}{lcccc}
\hline Sites & $\mathrm{Cu}$ & $\mathrm{Mn}$ & $\mathrm{Zn}$ & $\mathrm{Cr}$ \\
\hline Site $1(\mathrm{~S} 1)^{\mathrm{Ar}}$ & $0.868 \pm 0.25 \mathrm{a}$ & $\mathrm{bd}$ & $9.15 \pm 2.63 \mathrm{a}$ & $0.39 \pm 0.01 \mathrm{a}$ \\
Site 2 $(\mathrm{S} 2)^{\mathrm{Ar}}$ & $3.41 \pm 0.12 \mathrm{~b}$ & $\mathrm{bd}$ & $1.38 \pm 0.04 \mathrm{~b}$ & $0.07 \pm 0.02 \mathrm{~b}$ \\
Site 3 $(\mathrm{S} 3)^{\mathrm{Tt}}$ & $1.82 \pm 0.33 \mathrm{a}$ & $\mathrm{bd}$ & $2.30 \pm 0.68 \mathrm{~b}$ & $0.20 \pm 0.02 \mathrm{c}$ \\
\hline
\end{tabular}

The values shown are mean \pm SE (with $n=4,2,4)$ from S1, S2, and S3, respectively. bd, below detection limit.

In the present study, bioaccumulation was quantified in two species of mollusks (Agaronia razetoi and Tivela tripla). Previous studies have shown that Tivela tripla may be a likely prey of Agaronia razetoi [34]. Therefore, there is a potential for more heavy metal bioaccumulation in Agaronia razetoi than Tivela tripla because of biomagnification of metals at higher trophic levels. However, the results of the present study suggest that bioaccumulation of metals was not influenced by the trophic levels but by the metal and the organic matter in the coastal sediment. In this study, the major challenge associated with the analysis of bioaccumulation of metals in mollusks from the various sites was the unavailability of the same species of mollusks in the spatial areas studied. The availability of the same species of mollusks in the various sites studied would have made the comparison stronger.

The BSAF values in the present study tend to be lower for the mollusk in sediment with higher metal concentrations. The trend where BSAF values tend to be lower for benthic organisms in more contaminated sediment has been reported in other studies $[9,22,35]$. The BSAF values for $\mathrm{Zn}, \mathrm{Cu}$, and $\mathrm{Cr}$ across the different sites ranged from 1.38 to $9.15,0.87$ to 3.41 , and 0.07 to 0.39 , respectively. The BSAF values for $\mathrm{Zn}, \mathrm{Cu}$, and $\mathrm{Cr}$ in the present study are similar to what has been reported in other studies for these metals in coastal areas around the world $[6,10,36]$.

The organic matter in the coastal sediments also influenced the metal distribution in the sediment along the coast and in mollusks. The effect of the silt/clay content was not evident in this study. The sediment from Site 2 which had higher OM content had higher metal levels in the sediments compared to the other sites except for $\mathrm{Cu}$ which due to anthropogenic input was higher at Site 1. Trace metal bioaccumulation was higher in the mollusk from Site 2 except $\mathrm{Cr}$ which generally had low bioavailability and was not efficiently bioaccumulated by the mollusk. This observation agrees with previous studies which have shown that variation in metal levels in the sediment along the coast and in the mollusk is influenced by organic matter $[9,10,28]$. The organic matter in the sediment binds to the metals, decreases their release from the sediments, and thus increases metal levels in the sediment [9]. When the metals are retained in the sediment, this may increase their bioavailability to benthic organisms including mollusks through their diet or from their ambient environment. Some studies have shown increased bioaccumulation in bivalves because of increased organic matter in sediment [10].

\section{Conclusion}

The study shows that the trace metal levels in the coastal sediments of Accra and in the mollusks were below threshold levels. However, heavy metal levels in sediments except $\mathrm{Cu}$ tend to be higher in sediments with higher organic matter. The findings of this study also suggest that $\mathrm{Cu}$ levels in the sediment have an anthropogenic input. This is because the enrichment factor shows that $\mathrm{Cu}$ levels in the coastal sediments of Accra showed minimal to moderate enrichment. However, there was no enrichment for the other metals at all the other sites. There was bioaccumulation of $\mathrm{Zn}, \mathrm{Cu}$, and $\mathrm{Cr}$ in the mollusks; however, the concentration of $\mathrm{Cr}$ in the tissue relative to what is in the sediment suggests low bioavailability to the mollusks. Bioaccumulation of the heavy metals in the mollusk suggests that the gastropod (Agaronia razetoi) and the bivalve (Tivela tripla) can be used for biomonitoring of heavy metals.

\section{Data Availability}

Data, associated metadata, and calculation tools are available on request from the corresponding author (erblankson@ gmail.com).

\section{Conflicts of Interest}

The authors declare that they have no conflicts of interest.

\section{Acknowledgments}

The authors thank Mrs. R. Nkrumah, Mr. Quansah, Mr. Prince Owusu, and the staff of Ecological Laboratory, University of Ghana, who assisted with field and laboratory analysis.

\section{References}

[1] M. M. Ali, M. L. Ali, M. S. Islam, and M. Z. Rahman, "Preliminary assessment of heavy metals in water and sediment of Karnaphuli river, Bangladesh," Environmental Nanotechnology, Monitoring \& Management, vol. 5, pp. 2735, 2016.

[2] M. S. Islam, M. K. Ahmed, M. Raknuzzaman, M. Habibullah Al Mamun, and M. K. Islam, "Heavy metal pollution in surface water and sediment: a preliminary assessment of an urban river in a developing country," Ecological Indicators, vol. 48, pp. 282-291, 2015.

[3] F. Gbogbo and S. D. Otoo, "The concentrations of five heavy metals in components of an economically important urban 
coastal wetland in Ghana: public health and phytoremediation implications," Environmental Monitoring and Assessment, vol. 187, no. 10, p. 655, 2015.

[4] L. Méndez-Rodríguez, T. Zenteno-Savín, J. García-Hernández, and L. Acosta-Vargas, "Heavy metal levels in marine mollusks from areas with, or without, mining activities along the Gulf of California, Mexico," Archives of Environmental Contamination and Toxicology, vol. 57, no. 1, pp. 96-102, 2009.

[5] N. Zheng, Q. Wang, Z. Liang, and D. Zheng, "Characterization of heavy metal concentrations in the sediments of three freshwater rivers in Huludao City, Northeast China," Environmental Pollution, vol. 154, no. 1, pp. 135-142, 2008.

[6] O. Díaz Rizo, S. Olivares Reumont, J. Viguri Fuente et al., "Copper, zinc and lead enrichments in sediments from guacanayabo Gulf, Cuba, and its bioaccumulation in oysters, Crassostrea rhizophorae," Bulletin of Environmental Contamination and Toxicology, vol. 84, no. 1, pp. 136-140, 2010.

[7] A. B. Knutson, P. L. Klerks, and J. S. Levinton, "The fate of metal contaminated sediments in foundry cove, New York," Environmental Pollution, vol. 45, no. 4, pp. 291-304, 1987.

[8] P. Kelderman and A. A. Osman, "Effect of redox potential on heavy metal binding forms in polluted canal sediments in delft (The Netherlands)," Water Research, vol. 41, no. 18, pp. 4251-4261, 2007.

[9] C. Velez, E. Figueira, A. Soares, and R. Freitas, "Spatial distribution and bioaccumulation patterns in three clam populations from a low contaminated ecosystem," Estuarine, Coastal and Shelf Science, vol. 155, pp. 114-125, 2015.

[10] J. Liu, L. Cao, and S. Dou, "Bioaccumulation of heavy metals and health risk assessment in three benthic bivalves along the coast of Laizhou Bay, China," Marine Pollution Bulletin, vol. 117, no. 1-2, pp. 98-110, 2017.

[11] C. Rumisha, M. Elskens, M. Leermakers, and M. Kochzius, "Trace metal pollution and its influence on the community structure of soft bottom molluscs in intertidal areas of the dar es Salaam coast, Tanzania," Marine Pollution Bulletin, vol. 64, no. 3, pp. 521-531, 2012.

[12] Q. Zhou, J. Zhang, J. Fu, J. Shi, and G. Jiang, "Biomonitoring: an appealing tool for assessment of metal pollution in the aquatic ecosystem," Analytica Chimica Acta, vol. 606, no. 2, pp. 135-150, 2008.

[13] J. F. Elder and J. J. Collins, "Freshwater molluscs as indicators of bioavailability and toxicity of metals in surface-water systems," Reviews of Environmental Contamination and Toxicology, vol. 122, pp. 37-79, 1991.

[14] X. Wu, S. Wang, H. Chen et al., "Assessment of metal contamination in the Hun River, China, and evaluation of the fish Zacco platypus and the snail Radix swinhoei as potential biomonitors," Environmental Science and Pollution Research, vol. 24, no. 7, pp. 6512-6522, 2017.

[15] F. A. Otchere, C. R. Joiris, and L. Holsbeek, "Mercury in the bivalves Anadara (senilia) senilis, Perna perna and Crassostrea tulipa from Ghana," The Science of the Total Environment, vol. 304, no. 1-3, pp. 369-375, 2003.

[16] E. Nyarko and S. Evans, "Heavy metal pollution in marine mollusks from the coastal waters of Accra, Ghana," Journal of the Ghana Science Association, vol. 1, no. 1, pp. 105-112, 1998.

[17] H. Kuranchie-Mensah, J. Osei, S. M. Atiemo et al., "Heavy metal assessment of marine sediment in selected coastal districts of the Western Region, Ghana," Advances in Environmental Research, vol. 2, no. 2, pp. 155-166, 2013.

[18] C. K. Adokoh, E. A. Obodai, D. K. Essumang, Y. SerforArmah, B. J. B. Nyarko, and A. Asabere-Ameyaw, "Statistical evaluation of environmental contamination, distribution and source assessment of heavy metals (aluminum, arsenic, cadmium, and mercury) in some lagoons and an estuary along the coastal belt of Ghana," Archives of Environmental Contamination and Toxicology, vol. 61, no. 3, pp. 389-400, 2011.

[19] K. Pabis, R. Sobczyk, J. Siciński, T. Ensrud, and B. Serigstadt, "Natural and anthropogenic factors influencing abundance of the benthic macrofauna along the shelf and slope of the Gulf of Guinea, a large marine ecosystem off West Africa," Oceanologia, vol. 62, no. 1, pp. 83-100, 2020.

[20] K. A. Addo and I. A. Addo, "Coastal erosion management in Accra: combining local knowledge and empirical research," Jàmbá: Journal of Disaster Risk Studies, vol. 8, no. 1, 2016.

[21] A. Amekudzie, G. Emi-Reynolds, A. Faanu et al., "Natural radioactivity concentrations and dose assessment in shore sediments along the coast of Greater Accra, Ghana," World Applied Sciences Journal, vol. 13, no. 11, pp. 2338-2343, 2011.

[22] E. R. Blankson and P. L. Klerks, "The effect of bioturbation by Lumbriculus variegatus on transport and distribution of lead in a freshwater microcosm," Environmental Toxicology and Chemistry, vol. 35, no. 5, pp. 1123-1129, 2016.

[23] F. Cevik, M. Z. Göksu, O. B. Derici, and O. Findik, "An assessment of metal pollution in surface sediments of Seyhan dam by using enrichment factor, geoaccumulation index and statistical analyses," Environmental Monitoring and Assessment, vol. 152, no. 1, pp. 309-317, 2009.

[24] D. D. Macdonald, R. S. Carr, F. D. Calder, E. R. Long, and C. G. Ingersoll, "Development and evaluation of sediment quality guidelines for Florida coastal waters," Ecotoxicology, vol. 5, no. 4, pp. 253-278, 1996.

[25] R Core Team, R: A Language and Environment for Statistical Computing, R Foundation for Statistical Computing, Vienna, Austria, 2018, https://www.R-project.org/.

[26] J. Usero, J. Morillo, and I. Gracia, "Heavy metal concentrations in molluscs from the Atlantic coast of southern Spain," Chemosphere, vol. 59, no. 8, pp. 1175-1181, 2005.

[27] O. S. Ayodele, H. Y. Madukwe, and A. A. Adelodun, "Geoenvironmental evaluation of toxic metals in the sediments of Araromi coastal area, Southwestern Nigeria," Environmental Quality Management, pp. 1-19, 2021.

[28] K. D. Bastami, M. R. Neyestani, F. Shemirani, F. Soltani, S. Haghparast, and A. Akbari, "Heavy metal pollution assessment in relation to sediment properties in the coastal sediments of the southern Caspian Sea," Marine Pollution Bulletin, vol. 92, no. 1-2, pp. 237-243, 2015.

[29] J. I. Izegaegbe, L. Vivier, and H. M. Mzimela, “Trace metal contamination in sediment in the Mhlathuze Estuary, northern KwaZulu-Natal, South Africa: effects on the macrobenthic community," Environmental Monitoring and Assessment, vol. 192, pp. 401-418, 2020.

[30] E. R. Blankson, D. Oduro, J. Ewool, and F. Gbogbo, "The effect of heavy metals and physicochemical variables on benthic macroinvertebrate community structure in a tropical urban coastal lagoon," Community Ecology, vol. 22, pp. 147-156, 2021.

[31] L. Zhang, Z. Shi, Z. Jiang, J. Zhang, F. Wang, and X. Huang, "Distribution and bioaccumulation of heavy metals in marine organisms in east and west Guangdong coastal regions, South China," Marine Pollution Bulletin, vol. 101, no. 2, pp. 930-937, 2015.

[32] A. Cravo, M. J. Bebianno, and P. Foster, "Partitioning of trace metals between soft tissues and shells of Patella aspera," Environment International, vol. 30, no. 1, pp. 87-98, 2004. 
[33] P. Szefer and K. Szefer, "Metals in molluscs and associated bottom sediments of the southern Baltic," Helgoländer Meeresuntersuchungen, vol. 44, no. 3, pp. 411-424, 1990.

[34] N. J. Robinson and W. S. Peters, "Complexity of the prey spectrum of Agaronia propatula (Caenogastropoda: Olividae), a dominant predator in sandy beach ecosystems of Pacific Central America," PeerJ, vol. 6, Article ID e4714, 2018.

[35] D. K. DeForest, K. V. Brix, and W. J. Adams, "Assessing metal bioaccumulation in aquatic environments: the inverse relationship between bioaccumulation factors, trophic transfer factors and exposure concentration," Aquatic Toxicology, vol. 84, no. 2, pp. 236-246, 2007.

[36] R. V. Thomann, J. D. Mahony, and R. Mueller, "Steady-state model of biota sediment accumulation factor for metals in two marine bivalves," Environmental Toxicology and Chemistry, vol. 14, no. 11, pp. 1989-1998, 1995. 